\title{
Improvement of metabolic state in an animal model of nutrition-dependent type 2 diabetes following treatment with $S$ 23521, a new glucagon-like peptide 1 (GLP-1) analogue
}

\author{
G Üçkaya ${ }^{1}$, P Delagrange ${ }^{2}$, A Chavanieu ${ }^{3}$, G Grassy $^{3}$, \\ M-F Berthault ${ }^{4}$, A Ktorza ${ }^{4}$, E Cerasi ${ }^{1}$, G Leibowitz ${ }^{1}$ and $\mathbf{N}$ Kaiser $^{1}$ \\ ${ }^{1}$ Endocrinology and Metabolism Service, Department of Internal Medicine and The Hadassah Diabetes Center, Hadassah - Hebrew University Medical Center, \\ P.O. Box 12000, Jerusalem 91120, Israel \\ ${ }^{2}$ Institut de Recherches Internationales Servier (I.R.I.S.), 6 place des Pleiades, 92415 Courbevoie Cedex, France \\ ${ }^{3}$ Centre de Biochimie Structurale, CNRS UMR 5048-UM 1-INSERM UMR 554, 29 rue de Navacelles, 34090 Montpellier Cedex 5, France \\ ${ }^{4}$ Laboratoire de Physiopathologie de la Nutrition, CNRS UMR 7059, Université Paris 7, 75251 Paris, Cedex 05, France \\ (Requests for offprints should be addressed to N Kaiser; Email: kaiser@md.huji.ac.il)
}

\begin{abstract}
Glucagon-like peptide 1 (GLP-1) analogues are considered potential drugs for type 2 diabetes. We studied the effect of a novel GLP-1 analogue, S $23521\left(\left[\mathrm{a}^{8}\right.\right.$-des $\left.\mathrm{R}^{36}\right]$ GLP$1-[7-37]-\mathrm{NH}_{2}$ ), on the metabolic state and $\beta$-cell function, proliferation and survival in the Psammomys obesus model of diet-induced type 2 diabetes. Animals with marked hyperglycaemia after 6 days of high-energy diet were given twice-daily s.c. injection of $100 \mu \mathrm{g} / \mathrm{kg} \mathrm{S} 23521$ for 15 days. Food intake was significantly decreased in $\mathrm{S}$ 23251-treated P. obesus; however, there was no significant difference in body weight from controls. Progressive worsening of hyperglycaemia was noted in controls, as opposed to maintenance of pre-treatment glucose levels in the S 23521 group. Prevention of diabetes progression was associated with reduced mortality. In addition, the treated group had higher serum insulin, insulinogenic index and leptin, whereas plasma triglyceride and non-esterified fatty acid levels were decreased. S 23521 had pronounced effect
\end{abstract}

on pancreatic insulin, which was 5-fold higher than the markedly depleted insulin reserve of control animals. Immunohistochemical analysis showed islet degranulation with disrupted morphology in untreated animals, whereas islets from S 23521-treated animals appeared intact and filled with insulin; $\beta$-cell apoptosis was approximately $70 \%$ reduced, without a change in $\beta$-cell proliferation. S 23521 treatment resulted in a 2 -fold increase in relative $\beta$-cell volume. Overall, S 23521 prevented the progression of diabetes in $P$. obesus with marked improvement of the metabolic profile, including increased pancreatic insulin reserve, $\beta$-cell viability and mass. These effects are probably due to actions of S 23521 both directly on islets and via reduced food intake, and emphasize the feasibility of preventing blood glucose deterioration over time in type 2 diabetes.

Journal of Endocrinology (2005) 184, 505-513

\section{Introduction}

Type 2 diabetes results from failure to increase insulin secretion in the face of insulin resistance (Cerasi 1995, Kahn 2003). Studies in humans and animal models of type 2 diabetes show marked $\beta$-cell dysfunction characterized by defects in nutrient stimulus-secretion coupling, insulin gene transcription, biosynthesis and increased rate of $\beta$-cell apoptosis (Leibowitz et al. 2001a, Donath et al. 2003, Kahn 2003, Kaiser et al. 2003). Moreover, it was shown that $\beta$-cell mass is reduced in type 2 diabetes (Butler et al. 2003), which further limits insulin production.

Psammomys obesus, when fed a high-energy (HE) diet in captivity, develops a metabolic syndrome reminiscent of human type 2 diabetes with moderate obesity, insulin resistance, marked hyperglycaemia and hyperlipidaemia (Kalderon et al. 1986). Hyperglycaemia in P. obesus is associated with marked depletion of islet insulin content and increased $\beta$-cell apoptosis (Donath et al. 1999, Leibowitz et al. 2001 a, Kaiser et al. 2003). Defective stimulus-secretion coupling and reduced glucose-stimulated insulin production underlie the failure of pancreatic islets to increase insulin secretion in response to innate and acquired insulin resistance, emphasizing the central role of the $\beta$-cell in the pathogenesis of nutrition-dependent type 2 diabetes (Nesher et al. 1999, Leibowitz et al. 2001a). Therefore, $P$. obesus is an ideal model to study the effects of drugs that aim to improve $\beta$-cell function and survival. 
Glucagon-like peptide 1 (GLP-1) is a potent incretin hormone secreted by the intestinal L cells in response to food intake (Drucker 2001). GLP-1 exerts multiple effects on pancreatic $\beta$-cells, including stimulation of cAMP production, cytosolic calcium influx and glucosedependent insulin secretion (Drucker 2001). Moreover, GLP-1 stimulates insulin gene transcription and increases the expression and binding activity of PDX-1 (Buteau et al. 1999, Wang et al. 1999, 2001), a key factor in glucose-stimulated insulin gene transcription (Marshak et al. 1996). GLP-1 is required for normal glucose homeostasis; inhibition of its action decreases plasma insulin and increases blood glucose levels (Scrocchi et al. 1996). GLP-1 and its long-acting analogue exendin 4 were shown to expand the $\beta$-cell mass by inducing $\beta$-cell proliferation and neogenesis in different animal models of type 2 diabetes (Xu et al. 1999). This effect of GLP-1 is probably mediated by stimulation of PDX-1 expression (Wang et al. 1999, Xu et al. 1999). Furthermore, GLP-1/ exendin 4 treatment may also increase $\beta$-cell mass by suppressing $\beta$-cell apoptosis (Li et al. 2003).

In addition to its effect on the endocrine pancreas, GLP-1 has been shown to inhibit gastric motility in diabetic and non-diabetic subjects (Delgado-Aros et al. 2002, Meier et al. 2003). This reduces nutrient absorption, which diminishes the meal-induced glucose excursions and lowers the need for rapid insulin responses. In addition, GLP-1 and its long-acting derivatives have anorectic effects in humans and rodents (Flint et al. 1998, Gutzwiller et al. 1999), which result in long-lasting weight loss (Larsen et al. 2001). The effect of GLP-1 analogues on weight reduction together with their beneficial effects on $\beta$-cell mass and function render these compounds potential drugs for the treatment of type 2 diabetes.

A major obstacle for the use of GLP-1 in vivo is its rapid degradation, primarily by dipeptidyl peptidase IV (Deacon et al. 1995). S 23521 ([a ${ }^{8}$-des $\left.\mathrm{R}^{36}\right]$ GLP-1-[7-37]- $\mathrm{NH}_{2}$ ) is a novel GLP-1 analogue produced by engineering both the $\mathrm{N}$ - and C-termini of GLP-1; The L-alanine at position 8 was replaced with D-alanine and the arginine at position 36 was deleted. S 23521 was shown to be more stable than native GLP-1, whereas it shows similar binding to the GLP-1 receptor and an insulin-stimulating effect (de Menthière et al. 2004). In this study we have exploited the $P$. obesus model of type 2 diabetes to test the effects of S 23521 on the metabolic state of diabetic animals and on $\beta$-cell function and survival.

\section{Research design and Methods}

\section{Animals}

All studies were carried out on diabetes-prone P. obesus of both sexes, aged 2.5-3.5 months (Harlan, Jerusalem, Israel). After weaning at 3 weeks, animals were given a non-diabetogenic low-energy (LE) diet containing
$2.38 \mathrm{kcal} / \mathrm{g}$ (Koffolk, Petach Tikva, Israel), which maintained normoglycaemia (non-fasted blood glucose $<7 \cdot 8 \mathrm{mM}$ ). Diabetes, defined by random non-fasted blood glucose levels of $>8.3 \mathrm{mM}$ (Accutrend Sensor; Roche Diagnostics, Mannheim, Germany), was induced by giving an $\mathrm{HE}$ diet $(2.93 \mathrm{kcal} / \mathrm{g}$; Weizmann Institute of Science, Rehovot, Israel). Using this dietary manipulation, $90 \%$ of the animals develop hyperglycaemia within 5 days (Nesher et al. 1999). Animals were housed one per cage under standard light conditions (12 h:12 h light/dark cycle) and had free access to food and water. They were monitored by periodic measurements of body weight and tail-blood glucose. Since diabetes in $P$. obesus is dietdependent, food intake was monitored throughout the study. At termination of the in vivo study, animals were anaesthetized with ketamine hydrochloride (Ketalar; Parke-Davis, Gwent, Wales) and exsanguinated by cardiac puncture. The pancreas was rapidly removed and the head part frozen at $-80{ }^{\circ} \mathrm{C}$ for subsequent determination of insulin content after extraction in acid-ethanol, as described in Gadot et al. (1994); the tail part was immersionfixed in 10\% formalin, followed by paraffin embedding and sectioning. Multiple $5 \mu \mathrm{m}$ sections were prepared and used for immunohistochemical analysis of islet morphology and $\beta$-cell apoptosis and proliferation. Blood taken from the heart was used for glucose determination, and the collected sera stored at $-20{ }^{\circ} \mathrm{C}$ for further analysis of hormones, triglycerides and non-esterified fatty acids. All animal studies were approved by the Institutional Animal Care and Use Committee of the Hebrew University and the Hadassah Medical Organization.

\section{Formulation of the GLP-1 analogue S 23521}

S 23521 was prepared as a stock solution of $0.5 \mathrm{mg} / \mathrm{ml}$ in saline with $0 \cdot 1 \%$ BSA (saline-BSA) and aliquots kept frozen until used. Final dilutions, adjusted to give an injected volume of $0.2 \mathrm{ml} / 100 \mathrm{~g}$ animal body weight, were made in saline-BSA on the day of the experiment and discarded thereafter. Control animals were injected with saline-BSA. Treatments were administered by subcutaneous or intraperitoneal injections as indicated in the experimental protocols.

\section{Hormone assays}

Insulin determination Insulin was determined by RIA using anti-insulin-coated tubes from ICN Pharmaceuticals (Costa Mesa, CA, USA) and ${ }^{125}$ I-labeled insulin from Linco (St Charles, MO, USA). Human insulin standard from Novo-Nordisk (Bagsvaerd, Denmark) was used; cross-reactivity and dilution linearity were comparable to those determined previously (Gross et al. 1996). Hyperglycemic $P$. obesus produces varying amounts of insulin, proinsulin and proinsulin-conversion intermediates (Gadot et al. 1994), all of which cross-reacted with our 
assay antiserum; hence the term insulin is used for summed quantification of all insulin-like immunoreactive products in this study.

Glucagon and leptin determination Glucagon was determined in serum samples by the double-antibody RIA kit from Diagnostic Products Corporation (Los Angeles, CA, USA). Leptin was measured in serum samples by the Multi Species Leptin RIA Kit from Linco that resulted in parallel linear dilution curves for $P$. obesus, rat and human sera.

\section{Blood biochemistry assays}

Glucose was determined in whole blood using the Accutrend Sensor glucometer (Roche Diagnostics). Triglycerides and non-esterified fatty acids were measured in serum samples with the GPO-Trinder Kit (Sigma, St Louis, MO, USA) and the Half-Micro Test (Roche Diagnostics), respectively.

\section{Immunohistochemical studies}

及-cell replication For in vivo replication studies a monoclonal antibody to Ki-67 was used (Zymed, San Francisco, CA, USA). Paraffin sections were deparaffinized, rehydrated and endogenous peroxidase blocked by exposure to $3 \% \mathrm{H}_{2} \mathrm{O}_{2}$ for $15 \mathrm{~min}$. The slides were then rinsed in distilled water and heated in $10 \mathrm{mM}$ citrate buffer $(\mathrm{pH}$ 6.0) at $92{ }^{\circ} \mathrm{C}$ for $10 \mathrm{~min}$ in a microwave oven for antigen retrieval. After cooling at room temperature for at least $20 \mathrm{~min}$, the sections were rinsed in distilled water and washed three times with PBS and incubated with monoclonal mouse anti-Ki-67 antibody (Zymed) for $1 \mathrm{~h}$ at room temperature, followed by detection using a streptavidinbiotin-peroxidase complex developed with aminoethylcarbazole (Zymed). Subsequently, sections were incubated for $60 \mathrm{~min}$ at $37^{\circ} \mathrm{C}$ with guinea-pig anti-insulin antibody diluted 1:100 (Sigma) and detection performed with streptavidin-biotin-alkaline phosphatase complex developed with 5-bromo-4-chloro-indole phosphate/Nitro Blue Tetrazolium liquid substrate (Sigma).

DNA fragmentation The free $3^{\prime}-\mathrm{OH}$ strand breaks resulting from DNA degradation were detected with the terminal deoxynucleotidyl transferase-mediated dUTP-X 3' nick-end labeling (TUNEL) technique (Gavrieli et al. 1992). Pancreas sections were deparaffinized, rehydrated and incubated with $20 \mu \mathrm{g} / \mathrm{ml}$ proteinase $\mathrm{K}$ (BoehringerMannheim, Mannheim, Germany) for $15 \mathrm{~min}$ at $37^{\circ} \mathrm{C}$. Islet cultures were fixed and permeabilized as described above. Both tissue sections and cultured islets were then labeled by the TUNEL reaction according to the manufacturer's instructions (In Situ Cell Death Detection kit; Roche Diagnostics). The preparations were then rinsed with Tris-buffered saline, $\mathrm{pH} 7 \cdot 4$, and incubated
(10 min, room temperature) with 5-bromo-4-chloroindolyl phosphate/Nitro Blue Tetrazolium liquid substrate system, followed by staining for insulin as described above under $\beta$-cell replication and detection using streptavidin-biotin-peroxidase complex developed with aminoethylcarbazole.

Islet morphology Islet morphology was evaluated following immunostaining of deparaffinized, rehydrated sections for insulin, as above, or for glucagon using anti-glucagon antiserum (Immustain; Diagnostic Products Corporation), incubated for $1 \mathrm{~h}$ at $37^{\circ} \mathrm{C}$; detection was by streptavidinbiotin-peroxidase complex developed with aminoethylcarbazole. Sections were counterstained with hematoxylin.

\section{Morphometric analysis of relative $\beta$-cell volume}

Each pancreatic block was serially sectioned $(7 \mu \mathrm{m})$ throughout its length to avoid bias due to changes in islet distribution or cell composition, and then mounted on slides. For each pancreas, six to eight sections were randomly chosen at a fixed interval through the block (every 35th section). This procedure ensured that the selected sections are representative of the whole pancreas (Paris et al. 2003). Sections were immunostained for insulin using a peroxidase indirect-labelling technique. Briefly, sections were incubated for $1 \mathrm{~h}$ with a guinea-pig anti-insulin serum (final dilution 1:1000; ICN, Aurora, $\mathrm{OH}$, USA). Thereafter, sections were incubated for 45 min with peroxidase-conjugated rabbit anti-guinea-pig IgG (final dilution 1:20; Dako, Carpinteria, CA, USA). The activity of the antibody-peroxidase complex was revealed with 3,3'-diaminobenzidine-tetrahydrochloride (DAB) using a peroxidase substrate kit DAB (BiosysVector, Compiègne, France). A standard concentration of hematoxylin was added as a counterstain. After staining, sections were mounted in Eukitt (Kindler Gmbh, Freiburg, Germany). Islet cells whose staining ranged from very light to dark brown were considered as insulinpositive cells; therefore, even highly degranulated cells were counted as insulin-positive and included in the calculation of relative $\beta$-cell volume. Quantitative evaluation was performed using an Olympus $\mathrm{BH} 2$ microscope connected via a colour video camera to a computer, using Imagenia 2000 software (Biocom, Les Ulis, France). The area of insulin-positive cells, as well as that of total pancreatic sections, was evaluated in each section; $\beta$-cell area was then determined by calculating the ratio between the areas according to stereological methods. The results are expressed as relative $\beta$-cell volume in percent of total pancreas area (Butler et al. 2003).

In vivo experimental protocols

Acute studies Non-fasted P. obesus on LE diet were injected i.p. with different doses of S 23521 in saline-BSA 
(test) or the vehicle without the test compound (control). 5 min after administration of S 23521 the animals were injected with $50 \mathrm{mg} / \mathrm{ml}$ sodium thiopentone (Pentothal; Abbott) at a dose of $50 \mathrm{mg} / \mathrm{kg}$ to obtain light anesthesia. Intraperitoneal glucose tolerance test (IPGTT) was performed by injecting glucose $(500 \mathrm{mg} / \mathrm{ml})$ i.p. at a final dose of $1 \mathrm{~g} / \mathrm{kg} 15 \mathrm{~min}$ after the administration of S 23521. Blood was obtained from the heart at different time intervals during the glucose tolerance test for determination of glucose and insulin.

Chronic studies To evaluate the effect of S 23521 on progression of diabetes, normoglycaemic animals on LE diet were switched to the HE diet. After 6 days, when most animals exhibited hyperglycaemia, they were divided into two groups: the control group, receiving vehicle only by s.c. injections twice daily at 0800 and $1600 \mathrm{~h}$, and the test group receiving S 23521 at $100 \mu \mathrm{g} /$ $\mathrm{kg}$ body weight/injection. To assess the time course of the effect of S 23521 administration by i.p. injection on blood glucose, tail blood samples were collected on days 4, 7 and 14 of treatment before the morning injection (at $0800 \mathrm{~h}$ ) and at 3 and $8 \mathrm{~h}$ after S 23521 injection (at 1100 and $1600 \mathrm{~h}$ respectively). Animals were killed after 21 days of HE diet; S 23521 was not administered on the day of killing.

\section{Statistical analysis}

Results are expressed as means \pm S.E.M. When error bars are not shown, the S.E.M. was too small to be drawn. The non-parametric Mann-Whitney $U$ test was used to determine levels of significance where groups of data were compared. InStat statistical software from GraphPed Software (San Diego, CA, USA) was used for data evaluation. The significance level was set at $P<0 \cdot 05$.

\section{Results}

Acute effect of $S 23521$ on blood glucose and insulin secretion

IPGTT was performed on diabetes-prone P. obesus on LE diet to study the effect of S 23521 on insulin secretion in vivo. $50 \mu \mathrm{g} / \mathrm{kg} \mathrm{S} 23251$ reduced the $60-$ min mean blood glucose level by $36 \%$ (Fig. 1) and increased plasma insulin by approximately 5 -fold; lower doses of S 23251 had no effect on blood glucose and plasma insulin (data not shown).

\section{Treatment of diabetic P. obesus with S 23521}

Animals with hyperglycaemia after 6 days of HE diet (blood glucose $>11.1 \mathrm{mM}$ ) were assigned to receive twicedaily s.c. injections of $100 \mu \mathrm{g} / \mathrm{kg} \mathrm{S} 23521$ or vehicle. This dose was chosen for the chronic studies due to differences

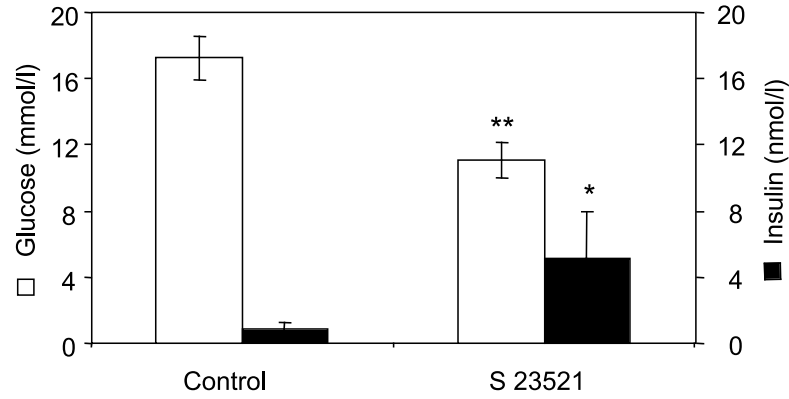

Figure 1 Mean blood glucose and serum insulin during $60 \mathrm{~min}$ IPGTT. IPGTT $(1 \mathrm{~g} / \mathrm{kg})$ was performed in animals injected with the test compound (S 23521) or vehicle (control) 15 min earlier. Blood was obtained from the hearts of lightly anaesthetized animals before glucose injection and at 10, 20, 30 and $60 \mathrm{~min}$ thereafter and used for determination of glucose and insulin concentrations. Results are shown as means \pm S.E.M. of blood glucose and insulin for between three and five animals in each group. ${ }^{*} P<0 \cdot 05,{ }^{* *} P<0 \cdot 02$ relative to controls by one-tailed Mann-Whitney $U$ test.

in the mode of administration in the chronic versus acute studies (s.c. versus i.p.). The characteristics of the animals that completed the study protocol (animals that died of severe hyperglycaemia were excluded from the final analysis) are presented in Table 1. Food intake was significantly decreased in the S 23251-treated P. obesus. However, there was no significant difference between test and control groups in body weight by the end of the study. Blood glucose levels were similar in test and control groups at the initial stage of HE-diet-induced diabetes (day 6 of HE diet). A progressive worsening of hyperglycaemia was noted during the following 15 days in the control group, as opposed to prevention of diabetes progression and maintenance of pre-treatment glucose levels in the S 23521 group (Fig. 2A). Only 2/18 (11.1\%) of animals treated with S 23521 died of severe hyperglycaemia during the course of the study, compared with $5 / 17(29 \cdot 4 \%)$ in the control group. The diurnal profile of blood glucose showed that glucose levels were lower in S 23521-treated $P$. obesus when determined before the morning injection on the fourth day of treatment (Fig. 2B). Glucose levels were decreased by approximately 50\% $3 \mathrm{~h}$ after injection of $\mathrm{S} 23521(14 \pm 1.4 \mathrm{mg} / \mathrm{dl}$ at time 0 compared with $7.5 \pm 1.5 \mathrm{mg} / \mathrm{dl}$ at $3 \mathrm{~h}$ ) and returned to pre-injection levels by $8 \mathrm{~h}$. A similar glucose-lowering effect was observed on days 7 and 14 of treatment (data not shown), indicating that the anti-hyperglycaemic effect of this compound is maintained over time.

In addition to the beneficial effect of S 23521 on blood glucose levels, the test group exhibited significantly higher levels of serum insulin (3-fold), insulinogenic index (7.5-fold) and leptin (50\% increase), whereas plasma triglycerides and non-esterified fatty acids were decreased significantly (Table 1 ). 
Table 1 Effect of S 23521 administration to diabetic $P$. obesus on metabolic parameters and pancreatic function. Values are expressed as means \pm S.E.M.

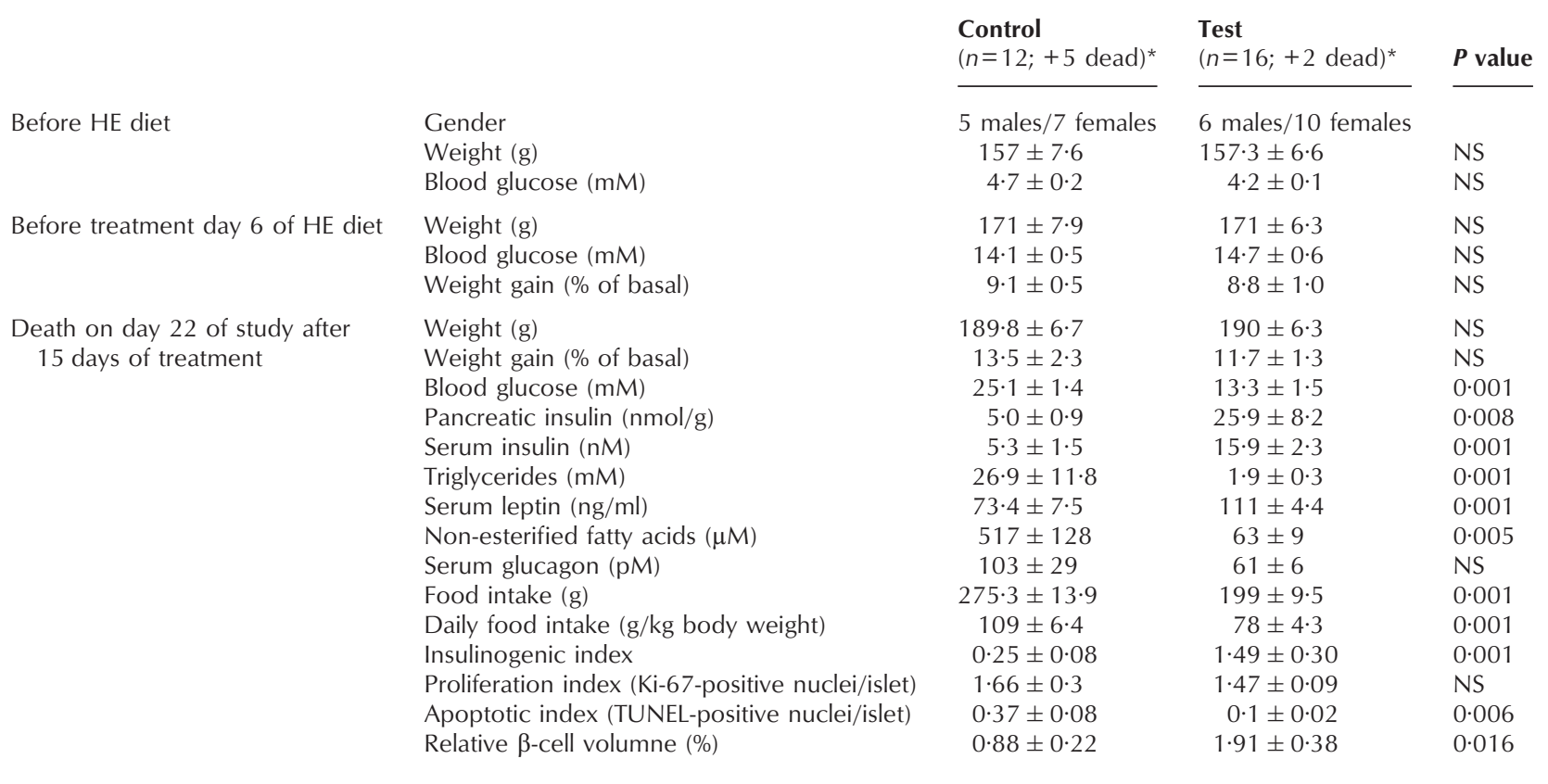

*Death from severe hyperglycaemia.

NS, not significant.

\section{Effects of $S 23521$ on pancreatic islets}

S 23521 had a pronounced effect on pancreatic insulin content, which was approximately 5-fold higher in the S 23521-treated P. obesus, as compared with the markedly depleted insulin reserve of control animals (Table 1). Immunohistochemical analysis of pancreatic sections from control animals showed marked depletion of islet insulin content with some disruption of islet architecture, whereas islets from S 23521-treated animals appeared relatively intact and filled with insulin (Fig. 3A-3D). HPLC analysis of pooled pancreatic extracts from S 23521-treated and control animals revealed similar HPLC profiles with proinsulin-like peptides comprising 62 and $65 \%$ of total IRI, respectively (results not shown). These results indicate that the partial replenishment of pancreatic insulin content was not sufficient to correct the elevation of proinsulin-like peptides induced by hyperglycaemia in P. obesus.

A higher number of TUNEL-positive nuclei was detected in $\beta$-cells of control animals compared with S 23521-treated animals (Fig. 3E and 3F), whereas the number of Ki-67-positive cells was similar between the two groups (Fig. $3 \mathrm{G}$ and $3 \mathrm{H}$ ). The apoptotic index (number of apoptotic $\beta$-cell nuclei per islet) was reduced by approximately $70 \%$ without modifying the proliferation index (Table 1), implying that the negative effect of chronic hyperglycaemia on $\beta$-cell survival was prevented by $S 23521$ treatment without affecting $\beta$-cell proliferation. This was associated with an approximately 2 -fold increase in $\beta$-cell volume relative to total pancreatic area (Table 1).

\section{Discussion}

The major finding in this study is that treatment of diet-induced diabetes with the GLP-1 analogue S 23521 can markedly improve the metabolic abnormalities of type 2 diabetes. This result is in accordance with the demonstration that different GLP-1 analogues are beneficial in other natural models of type 2 diabetes, such as $d b / d b$ mice and GK rats (Tourrel et al. 2002, Wang \& Brubaker 2002, Thorkildsen et al. 2003). S 23521 reduced blood glucose, plasma triglyceride and non-esterified fatty acid concentration; nevertheless, plasma triglycerides and glucose in treated animals remained higher that those previously observed in prediabetic P.obesus fed an LE diet (Donath et al. 1999, Nesher et al. 1999). Moreover, S 23521 treatment prevented glucose-induced $\beta$-cell apoptosis, resulting in increased $\beta$-cell mass and replenishment of islet insulin content. These metabolic changes were associated with decreased food intake but without change in body weight.

Similar to native GLP-1 (Drucker 2001), S 23521 had a direct stimulatory effect on pancreatic $\beta$-cells. 

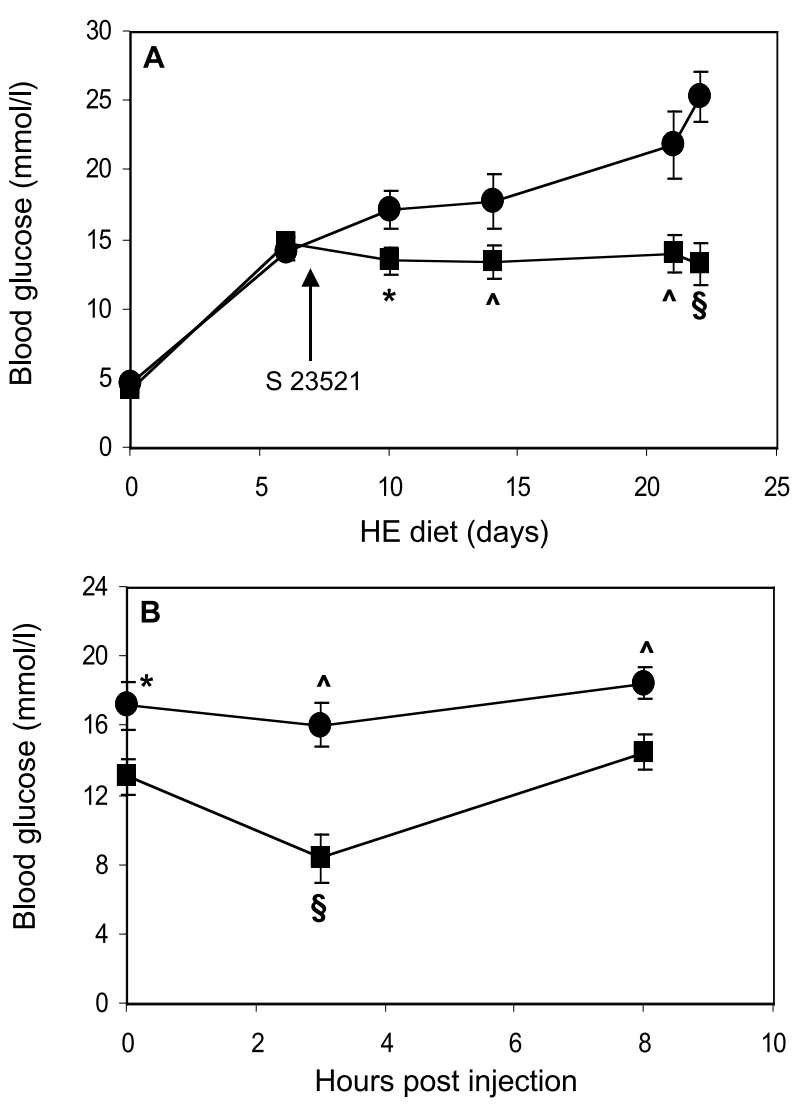

Figure 2 (A) Effect of 15-day S 23521 treatment on progression of diabetes in $P$. obesus. Prediabetic $P$. obesus were given HE diet on day 0 of the study. On day 7 , when animals were markedly hyperglycemic, they were treated for an additional 15 days by twice-daily s.c. injection of S $23521(100 \mu \mathrm{g} / \mathrm{kg}$ body weight $\times 2$;

口) or vehicle (1); the HE diet was continued until the end of the study on day 22. Non-fasted blood glucose concentrations were determined on the indicated days prior to the morning injection. No injections were administered on day 22. Results are shown as means \pm S.E.M. ${ }^{*} P<0 \cdot 05, \wedge P<0 \cdot 01, \S P<0 \cdot 001$ relative to controls. (B) Time course of the effect of $S 23521$ on blood glucose levels of diabetic $P$. obesus on the fourth day of treatment. Glucose was determined before the morning injection (time 0 ), $3 \mathrm{~h}$ thereafter and before the afternoon injection $(8 \mathrm{~h}) . \S P<0 \cdot 001$ relative to $S$ 23521 -treated animals at 0 and $8 \mathrm{~h}$. ${ }^{*} P<0 \cdot 05,{ }^{\wedge} P<0 \cdot 01$, control versus S 23521-treated animals at the same time points.

Serum insulin levels were increased following the administration of S 23521, which was accompanied by lower blood glucose concentrations. The stimulatory effect of S 23521 on insulin secretion was of relatively short duration (up to $1 \mathrm{~h}$ ). However, the glucose-lowering effect of S 23521 lasted much longer $(>3 \mathrm{~h}$ ) and was maintained up to 15 days, indicating that additional factors are important in the glucose-lowering effect of S 23521. Indeed, S 23521 induced a consistent and significant decrease of food intake. It is likely that the anorectic effect of GLP-1 plays a role in the improvement of diabetes in P. obesus. In this regard, it is of interest that reduced food intake did not result in lower body weight. This is in variance with other animal models in which the anorectic effect of GLP-1 was associated with reduced body weight (Farilla et al. 2002, Tourrel et al. 2002, Chang et al. 2003). We cannot explain the observed discrepancy between the GLP-1 effects on food intake and body weight in $P$. obesus. It is possible that the analogue reduces energy expenditure in the animals, or that the decrease in food intake induced by S-23521 was smaller compared with that observed with other GLP-1 analogues. In any case, the effect of the GLP-1 analogue in $P$. obesus cannot be explained by reduction of insulin resistance secondary to decreased body weight. This is in line with our observation that changing the diet of diabetic $P$. obesus to an LE diet resulted in rapid normalization of blood glucose without affecting body weight (Leibowitz et al. 2001b). Taken together, these data are in accordance with our previous observations on the development of diabetes in $P$. obesus, which results from failure of the islet to cope with the increased secretory demand induced by food intake (Gadot et al. 1994, 1995, Kaiser et al. 2003).

Why is pancreatic insulin content increased following treatment with S 23521? S 23521 may have a direct insulinotropic effect on pancreatic $\beta$-cells; indeed, GLP-1 analogues were shown to increase insulin gene expression in pancreatic $\beta$-cell lines (Buteau et al. 1999, Wang et al. 1999, Hui et al. 2002) and in animal models of type 2 diabetes (Xu et al. 1999, Perfetti et al. 2000, Tourrel et al. 2002). GLP-1 analogues can also increase the $\beta$-cell mass by induction of $\beta$-cell proliferation, differentiation and neogenesis (Xu et al. 1999, Buteau et al. 2001, Movassat et al. 2001). These effects are probably the result of increased PDX-1 expression and activity (Buteau et al. 1999, Wang et al. 2001). In this regard, it is of interest that $P$. obesus lack the conserved form of PDX-1 (Leibowitz et al. 2001a); therefore, the beneficial effects of S 23521 on insulin production in $P$. obesus are probably independent of PDX-1. GLP-1 analogues were also shown to inhibit cytokine- and streptozotocin-induced $\beta$-cell apoptosis (Li et al. 2003). We have shown previously that chronic hyperglycaemia induces $\beta$-cell apoptosis in $P$. obesus (Donath et al. 1999), probably mediated by increased interleukin-1 $\beta$ and Fas expression (Maedler et al. 2001, 2002). Our data suggest that GLP-1 analogues can also inhibit glucose-induced apoptosis, which could affect $\beta$-cell mass and augment pancreatic insulin content. Indeed, an approximately 2 -fold increase in relative $\beta$-cell volume was observed in S-23521-treated animals.

The design of the present study does not permit differentiation between direct effects of GLP-1 analogues on $\beta$-cell mass and function, and secondary effects due to improvement of hyperglycaemia and other metabolites; probably both mechanisms were operative. Indeed, decreased food intake may lower blood glucose, hence decrease glucose toxicity. Furthermore, serum nonesterified fatty acids and triglycerides were also reduced, 


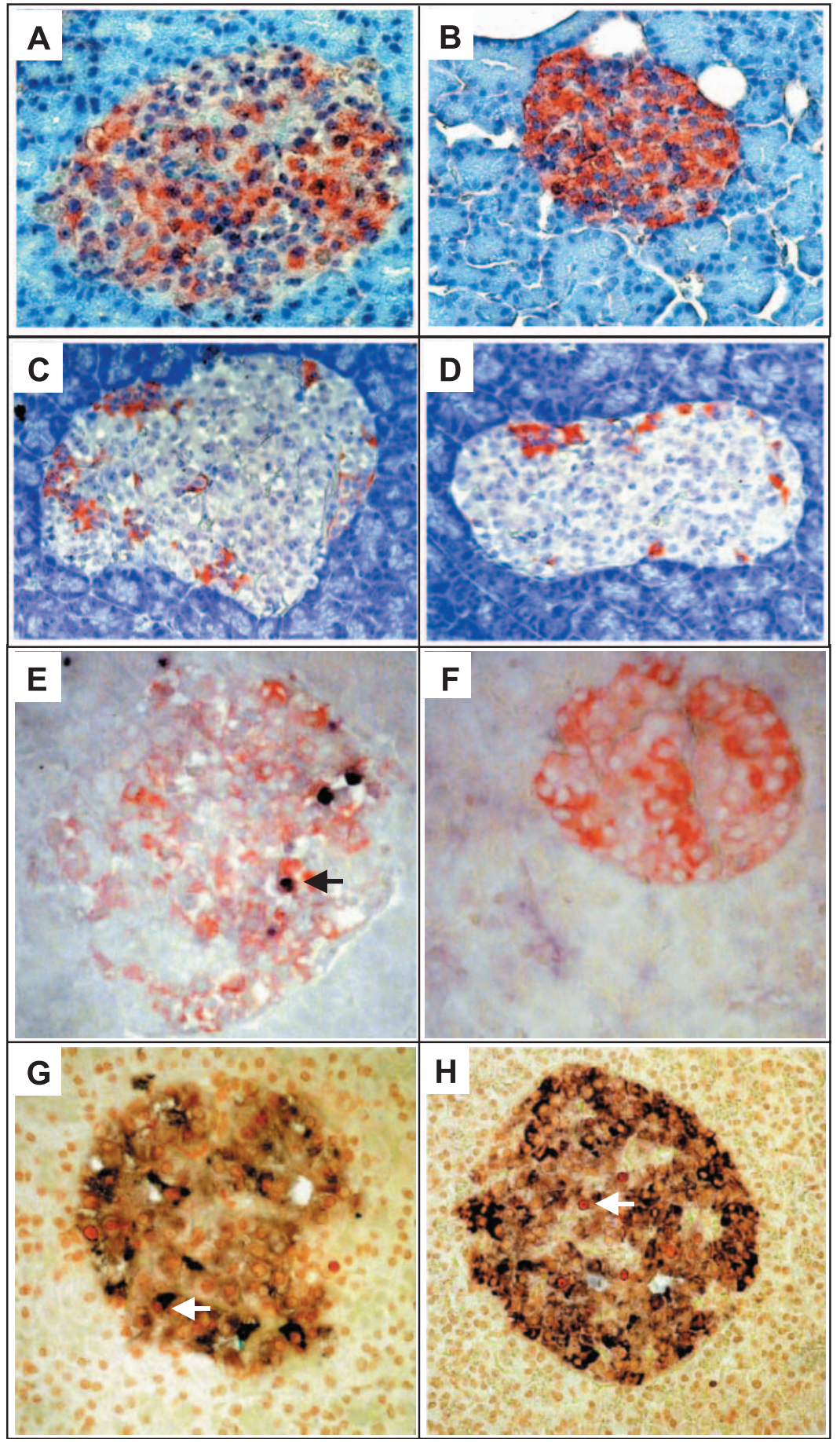

Figure 3 Photomicrographs of pancreatic sections of diabetic $P$. obesus treated for 15 days with vehicle or $S$ 23521. Animals were injected twice daily with vehicle (A, C, E, G) or $100 \mu \mathrm{g} / \mathrm{kg} \mathrm{S} 23521$ (B, D, F, H). Sections were immunostained for insulin (A and $\mathrm{B})$ or glucagon (C and $\mathrm{D})$ and counterstained with hematoxylin; insulin- and glucagon-positive cells are stained in dark orange. Pancreatic sections were double immunostained for insulin (dark orange) and DNA fragmentation (TUNEL; purple-black; E and F) or insulin (purple) and Ki-67 antigen (dark orange; G and H). The black arrow points at a TUNEL-positive $\beta$-cell in the islet in (E) and the white arrows point at Ki-67-positive $\beta$-cells in the islets in $(\mathrm{G})$ and $(\mathrm{H})$. Original magnification, $\times 200$. 
probably due to improved insulin secretion, thus contributing to the stabilization of diabetes in treated animals. On the other hand, we have recently shown that reduction of hyperglycaemia by phlorizin, while improving the metabolic state of the animals, had no effect on $\beta$-cell mass. Thus, our data support a direct effect of the GLP-1 analogue on $\beta$-cell mass in diabetic $P$. obesus due to reduced apoptosis.

Interestingly, there was a tendency for lower serum glucagon levels in S 23521-treated animals. A recent report suggested that glucagon secretion is mainly regulated by secreted insulin (Ishihara et al. 2003). It is likely that increased pancreatic insulin content together with increased insulin secretion inhibits glucagon secretion from pancreatic $\alpha$-cells of S 23521-treated $P$. obesus, in addition to the direct inhibitory effect of GLP-1 on glucagon release. Leptin levels were increased probably due to correction of insulin deficiency-induced lipolysis despite the reduction in food intake; it is unlikely that the GLP-1 analogue has direct effects since plasma leptin levels at early stages of diabetes were not altered (results not shown). Overall, the improved metabolic state of diabetic animals following S 23521 treatment can be explained by direct effects on pancreatic islets, together with the reduced food intake.

In conclusion, our data indicate that GLP-1 analogues exert multiple beneficial effects in nutrition-dependent type 2 diabetes. Improvement of hyperglycaemia and hyperlipidaemia is associated with a marked increase of islet insulin content, amelioration of glucose-induced apoptosis and increased $\beta$-cell mass. These findings further support the use of GLP-1 analogues in the treatment of type 2 diabetes, and emphasize the possibility that the deterioration of blood glucose concentration over time may be prevented.

\section{Acknowledgements}

This work was supported by a grant from Institut de Recherches International Servier (IRIS). The authors declare that there is no conflict of interest that would prejudice the impartiality of this scientific work.

\section{References}

Buteau J, Roduit R, Susini S \& Prentki M 1999 Glucagon-like peptide-1 promotes DNA synthesis, activates phosphatidylinositol 3-kinase and increases transcription factor pancreatic and duodenal homeobox gene 1 (PDX-1) DNA binding activity in beta (INS-1)-cells. Diabetologia 42 856-864.

Buteau J, Foisy S, Rhodes CJ, Carpenter L, Biden TJ \& Prentki M 2001 Protein kinase Czeta activation mediates glucagon-like peptide-1-induced pancreatic beta-cell proliferation. Diabetes $\mathbf{5 0}$ $2237-2243$

Butler AE, Janson J, Bonner-Weir S, Ritzel R, Rizza RA \& Butler PC 2003 Beta-cell deficit and increased beta-cell apoptosis in humans with type 2 diabetes. Diabetes 52 102-110.
Cerasi E 1995 Insulin deficiency and insulin resistance in the pathogenesis of NIDDM: is a divorce possible? Diabetologia 38 992-997.

Chang AM, Jakobsen G, Sturis J, Smith MJ, Bloem CJ, An B, Galecki A \& Halter JB 2003 The GLP-1 derivative NN2211 restores beta-cell sensitivity to glucose in type 2 diabetic patients after a single dose. Diabetes $\mathbf{5 2}$ 1786-1791.

Deacon CF, Johhnsen AH \& Holst JJ 1995 Degradation of glucagon-like peptide-1 by human plasma in vitro yields an $\mathrm{N}$-terminally truncated peptide that is a major endogenous metabolite in vivo. Journal of Clinical Endocrinology and Metabolism 80 952-957.

Delgado-Aros S, Kim DY, Burton DD, Thomforde GM, Stephens D, Brinmann BH, Vella A \& Camilleri M 2002 Effect of GLP-1 on gastric volume, emptying, maximum volume ingested and postprandial symptoms in humans. American Journal of PhysiologyGastrointestinal and Liver Physiology 282 G424-G431.

Donath MY, Gross DJ, Cerasi E \& Kaiser N 1999 Hyperglycemiainduced b cell apoptosis in pancreatic islets of Psammomys obesus during development of diabetes. Diabetes 48 738-744.

Donath MY, Storling J, Maedler K \& Mandrup-Poulsen T 2003 Inflammatory mediators and islet beta-cell failure: a link between type 1 and type 2 diabetes. Journal of Molecular Medicine 81 455-470.

Drucker DJ 2001 Minireview: the glucagon-like peptides. Endocrinology 142 521-527.

Farilla L, Hui H, Bertolotto C, Kang E, Bulotta A, Di Mario U \& Perfetti R 2002 Glucagon-like peptide-1 promotes islet cell growth and inhibits apoptosis in Zucker diabetic rats. Endocrinology 143 4397-4408.

Flint A, Raben A, Astrup A \& Holst JJ 1998 Glucagon-like peptide 1 promotes satiety and suppressesenergy intake in humans. Journal of Clinical Investigation 101 515-520.

Gadot M, Leibowitz G, Shafrir E, Cerasi E, Gross D \& Kaiser N 1994 Hyperproinsulinemia and insulin deficiency in the diabetic Psammomys obesus. Endocrinology 135 610-616.

Gadot M, Ariav Y, Cerasi E, Kaiser N \& Gross D 1995 Hyperproinsulinemia in the diabetic Psammomys obesus is a result of increased secretory demand on the B-cell. Endocrinology 136 4218-4223.

Gavrieli Y, Sherman Y \& Ben Sasson SA 1992 Identification of programmed cell death in vitro via specific labeling of nuclear DNA fragmentation. Journal of Cell Biology 199 493-501.

Gross DJ, Leibowitz G, Cerasi E \& Kaiser N 1996 Increased susceptibility of islets from diabetes-prone Psammomys obesus to the deleterious effects of chronic glucose exposure. Endocrinology 137 $5610-5615$.

Gutzwiller JP, Drewe J, Goke B, Schmidt H, Rohrer B, Lareida J \& Beglinger C 1999 Glucagon-like peptide-1 promotes satiety and reduces food intake in patients with diabetes mellitus type 2 . American Journal of Physiology - Regulatory Integrative and Comparative Physiology 276 R1541-R1544.

Hui H, Yu R, Bousquet C \& Perfetti R 2002 Transfection of pancreatic-derived beta-cells with a minigene encoding for human glucagon-like peptide-1 regulates glucose-dependent insulin synthesis and secretion. Endocrinology 143 3529-3539.

Ishihara H, Maecler P, Gjinovci A, Herrera PL \& Wollheim CB 2003 Islet beta-cell secretion determines glucagon release from neighbouring alpha-cells. Nature Cell Biology 5 330-335.

Kahn SE 2003 The relative contributions of insulin resistance and beta-cell dysfunction to the pathophysiology of Type 2 diabetes. Diabetologia 46 3-19.

Kaiser N, Leibowitz G \& Nesher R 2003 Glucotoxicity and beta-cell failure in type 2 diabetes mellitus. Journal of Pediatric Endocrinology and Metabolism 16 5-22.

Kalderon B, Gutman A, Levy E, Shafrir E \& Adler JH 1986 Characterization of stages in development of obesity-diabetes syndrome in the sand rat (Psammomys obesus). Diabetes 35 717-723. 
Larsen PJ, Fledelius C, Knudsen LB \& Tang-Christensen M 2001 Systemic administration of the long-acting GLP-1 derivative NN2211 induces lasting and reversible weight loss in both normal and obese rats. Diabetes 50 2530-2539.

Leibowitz G, Ferber S, Apelqvist A, Edlund H, Gross DJ, Cerasi E, Melloul D \& Kaiser N 2001a IPF1/PDX1 deficiency and beta-cell dysfunction in Psammomys obesus, an animal with type 2 diabetes. Diabetes 50 1799-1806.

Leibowitz G, Yuli M, Donath MY, Nesher R, Melloul D, Cerasi E, Gross DJ \& Kaiser N $2001 b$ Beta-cell glucotoxicity in the Psammomys obesus model of type 2 diabetes. Diabetes $\mathbf{5 0}$ (Suppl 1) 113-117.

Li Y, Hansotia T, Yusta B, Ris F, Halban PA \& Drucker DJ 2003 Glucagon-like peptide-1 receptor signaling modulates beta cell apoptosis. Journal of Biological Chemistry 278 471-478.

Maedler K, Spinas GA, Lehmann R, Sergeev P, Weber M, Fontana A, Kaiser N \& Donath MY 2001 Glucose induces beta-cell apoptosis via upregulation of the FAS receptor in human islets. Diabetes 50 1638-1690.

Maedler K, Sergeev P, Ris F, Oberholzer J, Joller-Jemelka HI, Spinas GA, Kaiser N, Halban PA \& Donath MY 2002 Glucose-induced beta cell production of IL-1 beta contributes to glucotoxicity in human islets. Journal of Clinical Investigation 110 851-860.

Marshak S, Totary H, Cerasi E \& Melloul D 1996 Purification of the beta-cell glucose-sensitive factor that transactivates the insulin gene differentially in normal and transformed islet cells. PNAS 93 15057-15062.

Meier JJ, Gallwitz B, Salmen S, Goetze O, Holst JJ, Schmidt WE \& Nauck MA 2003 Normalization of glucose concentrations and deceleration of gastric emptying after solid meals during intravenous glucagon-like peptide 1 in patients with type 2 diabetes. Journal of Clinical Endocrinology and Metabolism 88 2719-2725.

de Menthière SC, Chavanieu A, Grassy G, Dalle S, Salazar G, Kervran A, Pfeiffer B, Renard P, Delagrange P, Manechez D et al. 2004 Structural requirements of the $\mathrm{N}$-terminal region of GLP-1-[7-37]-NH2 for receptor interaction and cAMP production. European Journal of Medicinal Chemistry 39 473-480

Movassat J, Lopez AD, Beattie GB \& Hayek A 2001 Exendin-4 upregulates expression of PDX-1 and hastens differentiation and maturation of human fetal pancreatic B cells. Diabetes $\mathbf{5 0}$ (Suppl 2) A341.

Nesher R, Gross DJ, Donath MY, Cerasi E \& Kaiser N 1999 Interaction between genetic and dietary factors determines $\beta$-cell function in Psammomys obesus, an animal model of type 2 diabetes. Diabetes 48 731-737.

Paris M, Bernard-Kragar C, Berthault MF, Bouwens L \& Ktorza A 2003 Specific and combined effects of insulin and glucose on functional pancreatic $\beta$-cell mass in vivo in adult rats. Endocrinology $1442717-2727$.

Perfetti R, Zhou J, Doyle ME \& Egan JM 2000 Glucagon-like peptide- 1 induces cell proliferation and pancreatic-duodenum homeobox-1 expression and increases endocrine cell mass in the pancreas of old, glucose-intolerant rats. Endocrinology 141 4600-4605.

Scrocchi LA, Brown TJ, MaClusky N, Brubaker PL, Auerbach AB, Joyner AL \& Drucker DJ 1996 Glucose intolerance but normal satiety in mice with a null mutation in the glucagon-like peptide 1 receptor gene. Nature Medicine 2 1254-1258.

Thorkildsen C, Neve S, Larsen BD, Meier E \& Petersen JS 2003 Glucagon-like peptide 1 receptor agonist ZP10A increases insulin mRNA expression and prevents diabetic progression in $\mathrm{db} / \mathrm{db}$ mice. Journal of Pharmacology and Experimental Therapeutics 307 490-496.

Tourrel C, Bailbe D, Lacorne M, Meile MJ, Kergoat M \& Portha B 2002 Persistent improvement of type 2 diabetes in the Goto-Kakizaki rat model by expansion of the beta-cell mass during the prediabetic period with glucagon-like peptide-1 or exendin-4. Diabetes 51 1443-1452.

Wang Q \& Brubaker PL 2002 Glucagon-like peptide-1 treatment delays the onset of diabetes in 8 week-old $\mathrm{db} / \mathrm{db}$ mice. Diabetologia 45 1263-1273.

Wang X, Cahill CM, Pineyro MA, Zhou J, Doyle ME \& Egan JM 1999 Glucagon-like peptide-1 regulates the beta cell transcription factor PDX-1 in insulinoma cells. Endocrinology 140 4904-4907.

Wang X, Zhou J, Doyle ME \& Egan JM 2001 Glucagon-like peptide-1 causes pancreatic duodenal homeobox-1 protein translocation from the cytoplasm to the nucleus of pancreatic beta-cells by a cyclic adenosine monophosphate/protein kinase A-dependent mechanism. Endocrinology 142 1820-1827.

Xu G, Stoffers DA, Habener JF \& Bonner-Weir S 1999 Exendin-4 stimulates both beta-cell replication and neogenesis, resulting in increased beta-cell mass and improved glucose tolerance in diabetic rats. Diabetes 48 2270-2276.

Received 1 November 2004 Accepted 23 November 2004 